Travaux du Muséum National d'Histoire Naturelle «Grigore Antipa»

Vol. LV (1)

pp. $27-40$

(C) 31 août 2012

DOI: $10.2478 / \mathrm{v} 10191-012-0003-0$

\title{
A NEW SUBGENUS AND TWO NEW INDO-WEST-PACIFIC SPECIES OF THE LEPTOCHELIID GENUS PSEUDONOTOTANAIS LANG, 1973 (CRUSTACEA: TANAIDACEA: TANAIDOMORPHA)
}

MODEST GUȚU

\begin{abstract}
Makassaritanais, a new subgenus within the leptocheliid genus Pseudonototanais Lang, 1973 is diagnosed and two new species, Pseudonototanais (Makassaritanais) angustus and P. (M.) bamberi, are described, respectively, from the coasts of the islands Kalimantan (Makassar Strait) and Réunion (South-East of the Indian Ocean). Pseudonototanais (M.) modestus (Kussakin \& Tzareva, 1972), comb. nov., which was previously considered a synonym of Pseudonototanais werthi (Vanhoffen, 1914), is resurrected and transferred to the new subgenus. Based on these new observations six species of Pseudonototanais are now recognized, three within each of the two subgenera. An identification key for both males and females of the genus Pseudonototanais is presented.
\end{abstract}

Résumé. On décrit le sous-genre nouveau Makassaritanais, du genre Pseudonototanais Lang, 1973 de Leptocheliidae et deux espèces nouvelles, Pseudonototanais (Makassaritanais) angustus et P. (M.) bamberi des côtes de la Kalimantan îles (Détroit de Makassar) et de la Réunion (sud-est de l'océan Indien). Pseudonototanais (M.) modestus (Kussakin \& Tzareva, 1972), comb. nov., qui était considéré précédemment comme un synonyme de Pseudonototanais werthi (Vanhoffen, 1914) est transférés à de sous-genre nouveau. Sur la base de ces nouvelles observations, six espèces de Pseudonototanais sont reconnus maintenant, trois pour chaque sous-genre. On présente une clé d'identification pour les deux mâles et les femelles du genre Pseudonototanais.

Key words: Tanaidacea, Tanaidomorpha, Leptocheliidae, Pseudonototanais, Makassaritanais n. ssg.

Among the leptocheliids collected by the author from the Eastern Coast of the Kalimantan Island (Makassar Strait) during the expedition of "Grigore Antipa" National Museum of Natural History of Bucharest in the Indonesian Archipelago (1991), and among those from the Réunion Island (South-East of the Indian Ocean), sent for being studied by the late Dr. Hans-Georg Müller, I discovered two new species which I attribute to a new subgenus. The description of these new taxa is the subject of the paper.

Family Leptocheliidae Lang, 1973

Genus Pseudonototanais Lang, 1973

Genus Pseudonototanais was erected by Lang (1973), basing on the species Heterotanais werthi, briefly described by Vanhöffen (1914) from the Kerguelen Islands and re-described in detail by Shiino (1978) after a material collected from the same area, and by Sieg (1980) based on the type material. Later, two additional species, P. bransfieldensis Sieg, 1986 and P. ebriosus Bamber \& Bird, 1997, were added to the genus. The former was described by Sieg (1986) from the Subantarctic waters (Bransfield Strait) and the latter by Bamber \& Bird (1997) from the South China Sea (Hong Kong), both known only by female specimens. Beside these species, Kussakin \& Tzareva (1972) described the species Heterotanais modestus from the North-West Pacific (Kurile Islands), which was considered by Lang (op. 
cit.: 223) and Sieg (1973, cf. Shiino, op. cit., and Sieg, 1983) as junior synonym of Pseudonototanais werthi, a view not accepted by Shiino (op. cit.: 79).

Analyzing the morphological features of the two species, $P$. werthi and $H$. modestus, as it results from Shiino's (op. cit.), Sieg's (1980) and Kussakin \& Tzareva's (op. cit.) descriptions, I found that their females distinguish by the number of the setae from the maxilliped basis, the thickness of the pereopod $\mathrm{V}$ basis (in Kussakin \& Tzareva's description, op. cit., the references on the pereopods VI and VII are absent), by the number of the setae of the pleopods, as well as by the number of the articles of the uropod endopod. As regards the males of H. modestus, they have the antennules flagellum formed of three articles (probably four, the two authors, Kussakin and Tzareva, not observing the last articles because of their very tiny dimension) and the uropod endopod of two articles, while the males of $P$. werth $i$ have the antennules flagellum of two articles (the terminal one, very small, tuberculiform) and the uropod endopod, of three. In addition, the two species have a geographical distribution completely different (Kerguelen and Kurile Islands). In conclusion, I consider, as Shiino (op. cit.) did, that the species described by Kussakin \& Tzareva (op. cit.) is valid.

Also, I found that both females and males of the two new species, Pseudonototanais (Makassaritanais) angustus and P. (M.) bamberi, have some common features with $H$. modestus but shared with those of $P$. bransfieldensis, $P$. ebriosus and $P$. werthi. The females of these three latter species have two distal setae on the maxilliped basis, and pereopods V-VII have a more or less cylindrical basis (Bamber \& Bird, op. cit.: figs 17 F, 18 D-F; Shiino, op. cit.: figs 42 N, 43 F; Sieg, 1980: figs 13 Mxp and 15 P4, P5, P6; 1986: figs 3 Mxp, 4 P4, P5, P6), while the females of the species $P$. (M.) angustus n. sp. from the Makassar Strait has three (sometimes two) setae on the maxilliped basis (Fig. $1 \mathrm{~F}$ ), and pereopods V-VII have a swollen basis (Fig. 2 D, F). Females of $H$. modestus have only one seta on the maxilliped basis and, at least pereopod V, has a swollen basis (Kussakin \& Tzareva, op. cit.: fig. 3 d, i). Unfortunately, as I have mentioned, Kussakin \& Tzareva (op. cit.) did not make any specification regarding the basis of the pereopods VI and VII. Regarding the males of the two new species, they resemble those of $H$. modestus by the number of the articles of the antennules flagellum (four-five), but not with the male of P. werthi (type-species of the genus Pseudonototanais) whose antennules has a biarticled flagellum (including the tuberculiform terminal article). At present, the males of the other two species, P. bransfieldensis and P. ebriosus, are unknown.

In my opinion, the similarities between the two new species and H. modestus, on the one hand, and the differences between them and the other three species of the genus Pseudonototanais, on the other one, suggest the presence of two evolutionary lines which should be pointed out by the classification of the two "groups" in different genera or subgenera. But, taking into consideration the presence of some major common features in all six known species (I refer especially to the number of the foliaceous setae, or "tooth-like spines", cf. Bamber \& Bird, op. cit.: 123, on the maxilliped endite of the females, the configuration of the male chelipeds, as well as, other morphological features) I chose classify them within two subgenera. The unknown males of the species P. bransfieldensis and P. ebriosus, and the unknown female of one of the new species prevented me to classify the respective species in a new genus, considering that the statute of a subgenus is much appropriate, for the time being. 
Diagnosis of the genus Pseudonototanais (modified after Lang, op. cit., and Sieg, 1980).

Females. Body more or less dorso-ventrally flattened. Carapace ovate, with well defined eye lobes; eyes pigmented. Antennules with three-articled peduncle and a very small one-articled flagellum. Antenna six-articled, including the tuberculiform terminal article; second article with two spine-like setae, distodorsally and distoventrally; third article with only one distodorsal spine-like seta. Maxillules endite with nine stout spines; palp with two setae. Mandibles with short but thick molar process having the masticatory surface serrated or with numerous spinules; lacinia mobilis of left mandible broad, with some denticles on outer margin. Maxilliped basis unfused; endite with one long simple and two short foliaceous setae, and one to three distoinner coupling hooks on the distal margin. Cheliped as in other leptocheliid genera. Pereopods II-IV basis slender; pereopods V-VII basis cylindrical or swollen. Pleopods biramous, in five pairs, with well developed rami. Uropods biramous; exopod uni- or bi-articled; endopod multi-articled.

Males. Carapace slightly narrower anteriorly; eye as in female. Antennules peduncle three-articled; first article shorter than carapace length and at most twice as long as second article; flagellum two-articled at least (including the tuberculiform terminal article). Antenna six-articled, including the short terminal article. Mouthparts atrophied. Cheliped, shorter than carapace and first two pereonites combined; propodus, much modified, is characterized by a short but broad palm and curved and ventrally oriented fixed finger; dactylus slender and curved; basis, merus and carpus relatively similar to those of the female. Pereopods II-IV basis slender; pereopods V-VII basis slightly swollen. Pleopods as in female. Uropods exopod as in female; endopod as in female or not.

Type species: Heterotanais werthi Vanhöffen, 1914.

Composition (2 subgenera): Pseudonototanais Lang, 1973, sensu stricto, and Makassaritanais n. ssg.

Remarks. The main features by which the genus Pseudonototanais can be easily distigushed by other leptocheliid genera (and especially by the genus Leptochelia), consist in the number of stout spines of the maxillule endite (nine in Pseudonototanais, and eleven in Leptochelia) and of the foliaceous setae of maxilliped endite (three in Leptochelia, comparatively to two in Pseudonototanais), in females, and by the configuration of chelipedal propodus in males.

\section{Subgenus Pseudonototanais Lang, 1973, sensu stricto}

Diagnosis. Females. Mandibles molar process with serrated masticatory surface. Maxilliped basis with two distal simple setae. Pereopods V-VII basis more or less cylindrical. Uropods exopod uni- or bi-articled. Males. Antennule flagellum short, bi-articled, including the small (tuberculiform) terminal article.

Type species: Heterotanais werthi Vanhőffen, 1914.

Composition (3 species): Pseudonototanais (Pseudonototanais) bransfieldensis Sieg, 1986, P. (P.) ebriosus Bamber \& Bird, 1977 and P. (P.) werthi (Vanhöffen, 1914). (The males of the first two species are unknown). 


\section{Subgenus Makassaritanais n. ssg.}

Diagnosis. Females. Mandibles molar process with numerous spinules on the masticatory surface. Maxilliped basis with a different number of simple setae. Pereopods V-VII basis swollen. Uropods endopod one-articled. Males. Antennules flagellum three-articled at least, including the tuberculiform terminal article.

Type species: Pseudonototanais (Makassaritanais) angustus $\mathrm{n}$. sp.

Etymology. After the geographical marine area from which the type-species was collected (Makassar Strait), and "tanais".

Composition (3 species): Pseudonototanais (Makassaritanais) angustus $\mathrm{n}$. sp., P. (M.) bamberi n. sp. and P. (M.) modestus (Kussakin \& Tzareva, 1972), comb. nov. (The species $P$. (M.) bamberi $\mathrm{n}$. sp. is known only after males).

Remarks. As it results from diagnoses, the females of the two subgenera differ by (1) the presence or absence of the spinules of masticatory surface of mandible molar process, (2) the number of the setae of maxilliped basis, and (3) the configuration of pereopods V-VII basis (cylindrical or swollen). The males differ by the number of antennule flagellum articles (two or more).

By the thickness of pereopods V-VII basis of females, the species of the subgenus Makassaritanais n. ssg. resemble species of other leptocheliid genera, but especially those of the genus Leptochelia Dana, 1849.

By the number of the foliaceous setae or "tooth-like" (cf. Bamber \& Bird, op. cit.: 123) from the maxilliped endite, by the thickness of the pereopods V-VII basis in females, and by the configuration of the males' antennules, the species Leptochelia lusei Bamber \& Bird, 1997 resembles those of the subgenus Makassaritanais $\mathrm{n}$. ssg., the only major difference being in the cheliped configuration in males. I do not exclude the possibility that this difference to be caused by the "origin" of the described males ("primary", in the species L. lusei, as results from Bamber \& Bird, op. cit.: 125, and "secundary", in the three species of the subgenus Makassaritanais n. ssg., figs 3 C, 4 D, Kussakin \& Tzareva, op. cit.: fig. 4 d). If my hypothesis is correct, L. lusei belongs to the subgenus Makassaritanais n. ssg.

\section{Pseudonototanais (Makassaritanais) angustus n. sp.}

(Figs 1-3)

Material: 7 specimens (4 non-ovigerous females, one of which conserved in bad condition was distroyed by dissection, and 3 males), Bontang (Strait of Makassar, Indonesia), Station 12, collected on bottom of coarse sand with fragments of dead corals and mollusc shells, without vegetation, 3 m deep, 18 May, 1991; Leg. Dr. Modest Guţu.

Holotype, non-ovigerous female, preserved in the collections of "Grigore Antipa" National Museum of Natural History, No. 254506;

Allotype, male, in the same collections, No. 250507;

Paratypes, 2 females and 2 males, in the same collections, No. 250508.

Etymology, after the Latin angustus, "narrow", "slender", referring to the thickness of the female chelipedal carpus.

Description of non-ovigerous female

Body (Fig. 1 A) slightly dorsoventrally flattened, 7.5 times as long as maximum width; standard length, about $2.1 \mathrm{~mm}$. 


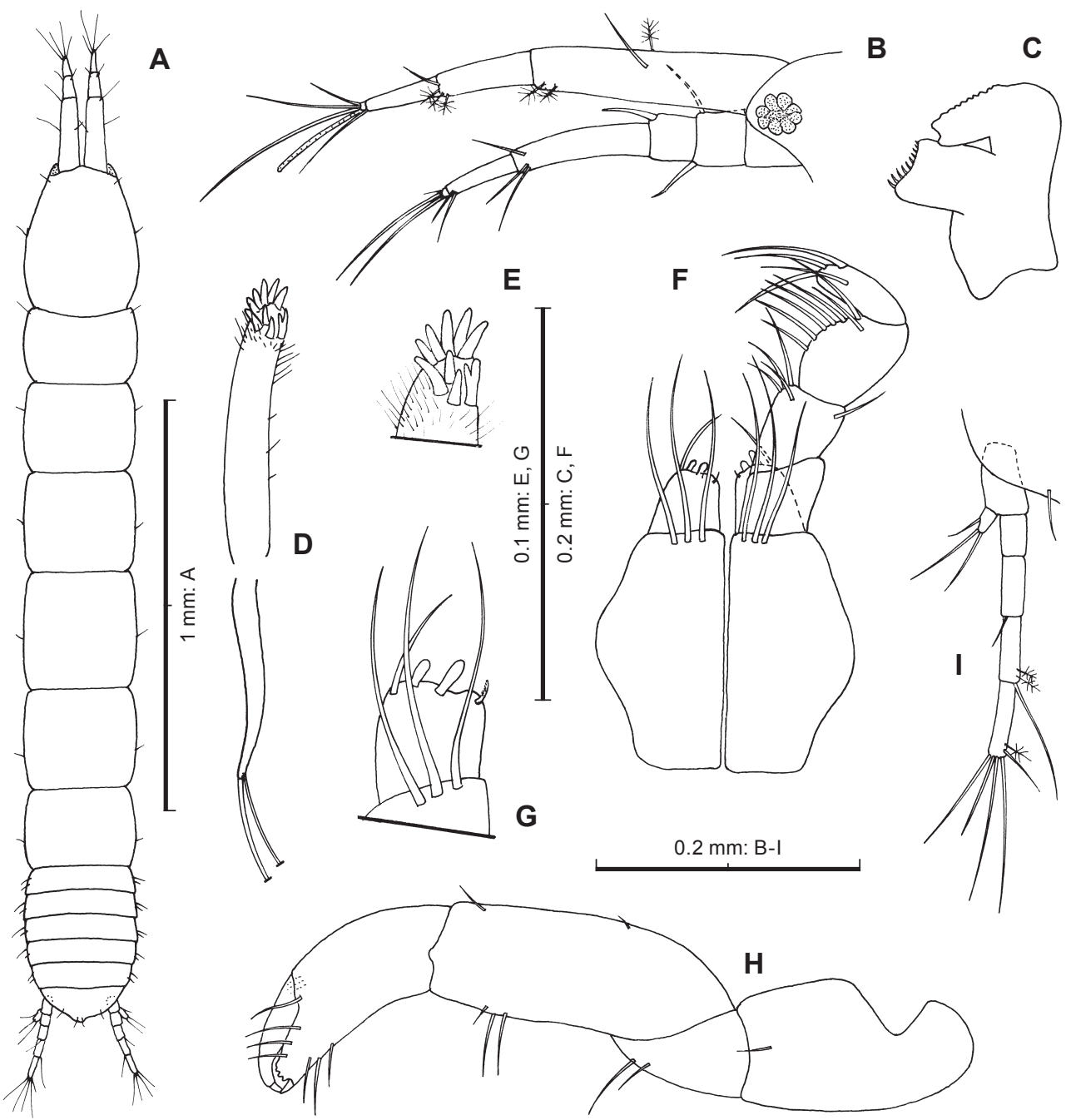

Fig. 1 - Pseudonototanais (Makassaritanais) angustus n. ssg., n. sp., female, paratype: A, body, dorsal; B, antennule and antenna, lateral; C, mandible, right; D, maxillule (schematic); E, same, endite terminal spines; F, maxillipeds (palp of maxilliped not shown); G, maxillipedal endite; $\mathrm{H}$, cheliped, left; I uropod, left.

Carapace ovate, 1.3 times as long as broad and approximately as long as first two pereonites combined, with two small setae on the first half of sides. Eyelobes distinct; visual elements pigmented.

Pereon five times as long as wide. Pereonites slightly rounded laterally; first pereonite 1.6 times as wide as long, with one short seta in each anterolateral corner; pereonites two to six, respectively 1.2,1.1, 0.9, 1.1 and 1.4 times as wide as long, with one short seta on sides.

Pleon, about as long as first two pereonites together and 1.4 times as long as wide, with five very short pleonites (each of them having two setulae on sides) and a pleotelson slightly longer than any pleonite having four short setae on caudal side. 
Antennule (Fig. 1 B) with three-articled peduncle and one-articled flagellum. First peduncular article, five times as long as wide and about 2.5 times longer than second article, with one-two simple and some broom setae; second article, thinner than previous, with one simple and three broom setae; third article, thinner and shorter than the second article, with one aesthetasc and one long simple seta. Flagellum (tuberculiform) with three distal long simple setae.

Antenna (Fig. 1 B) six-articled, slightly longer than first two peduncular articles of antennule; second article short, as long as wide, with two distal setiform spine (tergally and sternally); third article as long as preceding article, with one distotergal spine; fourth article, about as long as previous three together, but thinner than these, with three distal simple setae; fifth article half as long as fourth article, with two distal short setae; sixth article tuberculiform, with two long simple setae.

Mandibles with short but thick molar process bearing numerous short spinules on masticatory surface. Pars incisiva of right mandible with outer margin slightly crenulated and a bifid apex (Fig. 1 C). Pars incisiva and lacinia mobilis of left mandible with four and five small denticles, respectively.

Maxillule (Fig. 1 D) with two long distal setae on palp and a crown of nine terminal spines (one of them bifid) on endite (Fig. $1 \mathrm{E}$ ).

Maxillipeds (Fig. $1 \mathrm{~F}$ ) not fused, without coxa. Basis twice as long as maximum width, with three distal long simple setae. Palp four-articled; setulation as figured. Endite with one simple and two short foliaceous setae, and one coupling hook on distal margin (Fig. $1 \mathrm{G}$ ).

Cheliped (Fig. $1 \mathrm{H}$ ) relatively slender, approximately 6.7 times as long as carpus width. Basis 1.7 times as long as median broad, with one distal short seta. Merus triangular, with two unequal sternal setae. Carpus narrow, 2.5 times as long as wide, having three sternal and two tergal setae, as figured. Propodus approximately as long as basis and about 2.5 times as long as wide; fixed finger one-half as long as palm, with four and three setae on the inner and outer margins, respectively; unguis short. Dactylus curved, as long as fixed finger but thinner than that; unguis small.

Pereopod II (Fig. 2 A) much longer than the following pereopods. Basis four times as long as median width, with one simple and one broom seta, proximosternally. Ischium with one short seta. Merus smooth, about one-third as long as basis. Carpus, slightly longer than merus, with one distosternal and two longer distotergal setae. Propodus as long as ischium, merus and carpus combined, slightly swollen proximally; setation as figured. Dactylus (including unguis) longer than propodus; unguis shorter than dactylus.

Pereopod III (Fig. 2 B) slender. Basis relatively cylindrical, three times as long as wide. Ischium with one short seta. Merus smooth, as long as basis width. Carpus slightly longer than merus; distally with one spine and two short setae, as figured. Propodus, about as long as merus and carpus together, with two distal setae. Dactylus as long as merus; unguis small.

Pereopod IV (Fig. 2 C) relatively similar to pereopod III but a little smaller than that. Merus with only two distal setae and propodus with one small distosternal spine and one distotergal seta.

Pereopod V (Fig. 2 D) as long as pereopod IV. Basis swollen, two times as long as broad. Ischium with one short seta. Merus short, as long as wide, with two very small distosternal spines. Carpus 1.5 times as long as merus, with two distal spines. Propodus as long as carpus but thinner than that, with two distotergal setae and one distosternal spine. Dactylus short, curved; unguis small. 


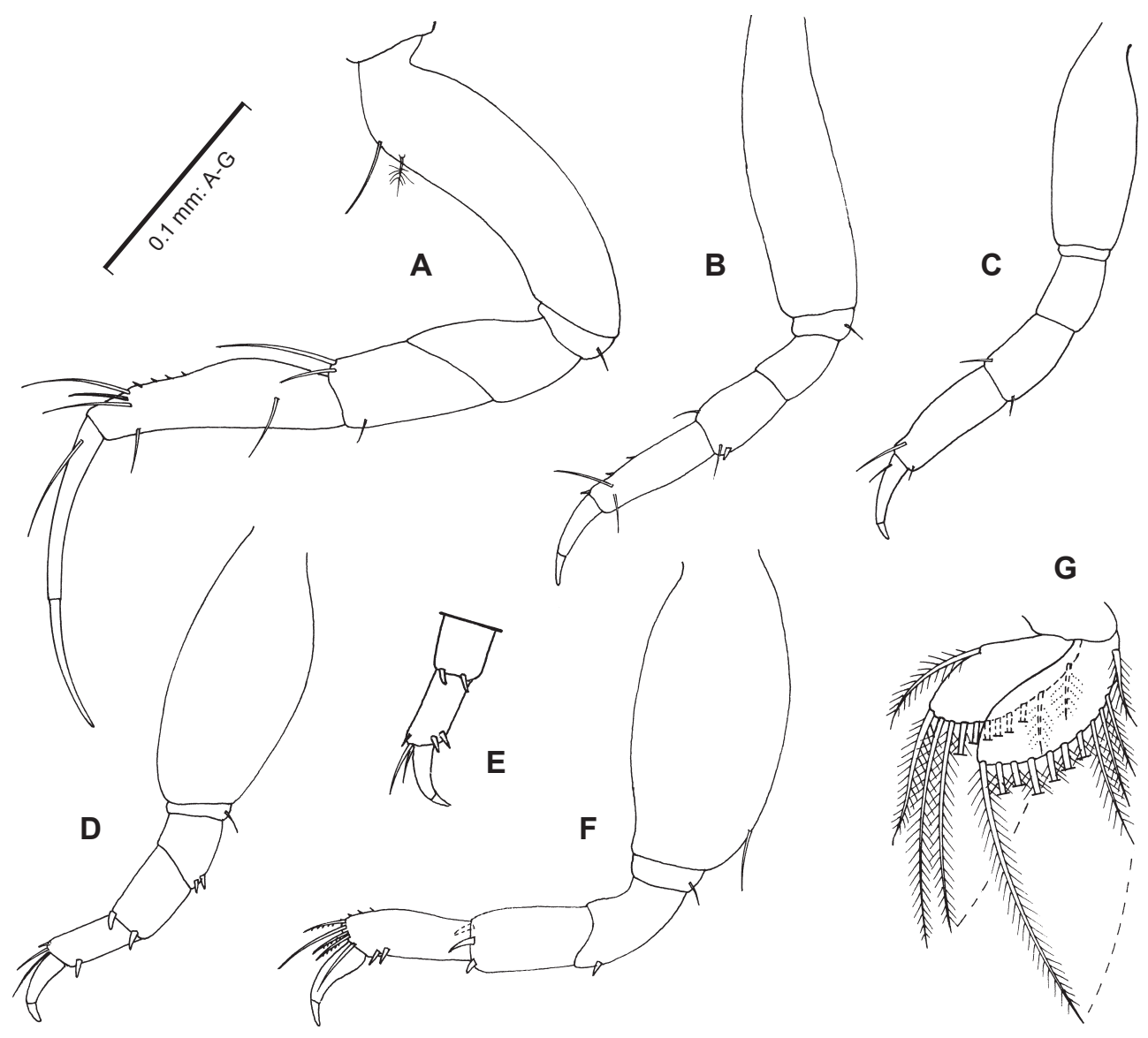

Fig. 2 - Pseudonototanais (Makassaritanais) angustus n. ssg., n. sp., female, paratype: A-D, pereopods II-V, respectively; E, carpus (distal half), propodus and dactylus of pereopod VI; F, pereopod VII; $\mathrm{G}$, pleopod.

Pereopod VI similar to previous pereopod, but with two distosternal spines on propodus (Fig. 2 E).

Pereopod VII (Fig. 2 F) stronger than pereopods V or VI. Basis swollen, two times as long as broad, with one distosternal seta. Ischium with one sternal seta. Merus one-quarter as long as basis and aproximately 1.5 times as long as wide, with one distosternal small spine. Carpus 1.7 times as long as merus, with three distal spines. Propodus as long as carpus but slightly thinner than that, with two distosternal spines and five distotergal setae, three of them shorter.

Pleopods (Fig. 2 G) well developed. Peduncle short and thick. Endopod with one midinner and eleven plumose setae on outer margin. Exopod also with eleven plumose setae on outer side.

Uropod (Fig. 1 A, I) biramous. Protopod longer and thicker than first endopodal article. Exopod very small, with one short midexternal and two long distal setae. Endopod slender, four-articled, as long as first three pleonites together; setulation as in drawing. 


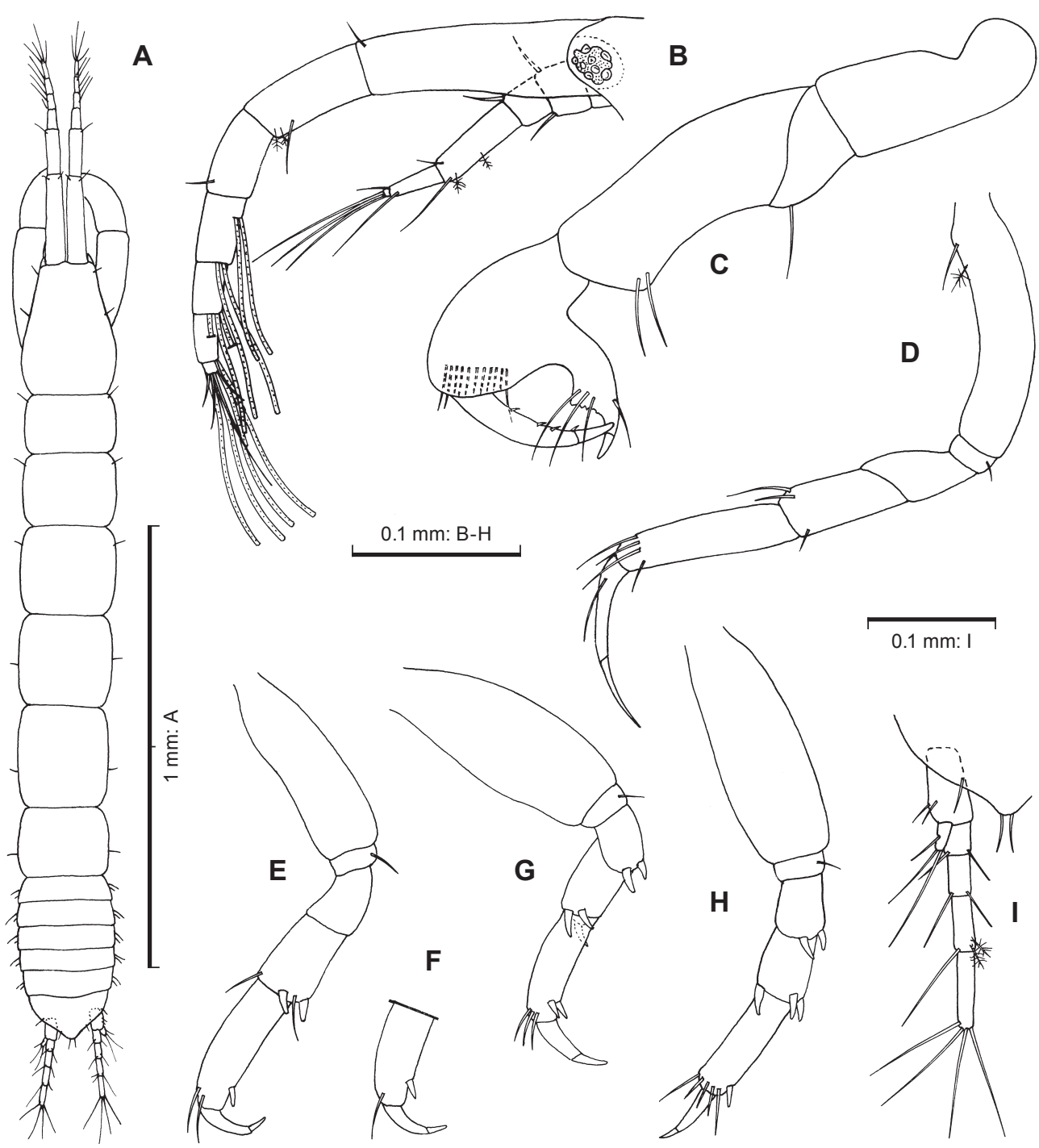

Fig. 3 - Pseudonototanais (Makassaritanais) angustus n. ssg., n. sp., male, holotype (A) and paratype (B-I): A, body, dorsal; B, antennule and antenna, lateral; C, cheliped, left; D, E, pereopods II and III, respectively; F, propods (distal half) and dactylus of pereopod IV; G-H, pereopods V and VII, respectively; I, uropod, left.

Variability. The number of distal setae of maxilliped basis can be different (two or three) in the two maxillipeds of the same female. Also, the uropodal endopod can have only three articles.

Description of male.

Body (Fig. 3 A) 8.5 times as long as wide at the level of the first pereonite; standard length, $1.7 \mathrm{~mm}$. 
Carapace slightly narrower anteriorly, 1.3 times as long as maximum width, with two setae on first half of sides. Eyes as in female.

Pereon five times as long as wide; pereonites 1-6 subrectangular, respectively 1.6, 1.3, 1.1, 1.1, 1 and 1.4 times as wide as long; setulation as in female.

Pleon longer than first two pereonites combined and approximately 1.7 times as long as wide; setulation as in female.

Antennule (Fig. 3 B) seven-articled, 1.6 times as long as carapace; first peduncular article two times as long as second article; flagellum four-articled (including the terminal, tuberculiform, article), each article having two or three long aesthetascs; terminal article with three relatively short setae.

Antenna (Fig. 3 B) six-articled, slightly longer than the first peduncular article of antennule; second article with two distal setae (tergally and sternally); third article with only one distotergal seta; fourth article a little longer than the previous two articles combined but thinner than those; fifth article thin, 1.5 times as long as third article; sixth article very short (tuberculiform); setulation as figured.

Mouthparts atrophied.

Cheliped (Fig. 3 C) slightly longer than the antennules (measured without aesthetascs). Basis 2.2 times as long as wide. Merus short, triangular, with one distosternal seta. Carpus as long as basis and merus combined and 2.2 times as long as median width, with two distosternal setae. Propodus with short but wide palm and a very curved fixed finger (sickle-like); distally (on the inner surface), near the dactylus insertion with a vertical comb-row of 13 setae; fixed finger thin, with a midinner expansion and four setae; unguis stout. Dactylus slender, curved, with four or five spinules on the inner margin; unguis longer than its symmetrical.

Pereopod II (Fig. 3 D) slender, as in female, excepting the length of dactylus (combined with unguis) which is shorter than propodus.

Pereopod III (Fig. 3 E) and $I V$ similar. Basis 3.2 times as long as wide. Ischium with one sternal seta. Merus smooth, as long as basis width. Carpus as long as ischium and merus combined; distally with two spines and two setae. Propodus as long as two previous articles, with one distosternal spine and two distotergal setae in pereopod III and only one seta in pereopod IV (Fig. 3 F). Dactylus thin, curved, shorter than merus; unguis small.

Pereopod V (Fig. $3 \mathrm{G}$ ) and VI similar, as large as pereopod III or IV. Basis slightly swollen, 2.5 times as long as wide. Ischium with a sternal seta. Merus short, with two distosternal spines. Carpus a little longer than merus, with three distal spines. Propodus 1.5 times as long as carpus with three distotergal setae and two distosternal spines. Dactylus as in previous two pereopods.

Pereopod VII (Fig. $3 \mathrm{H}$ ) differs from pereopods V or VI by the number of propodal setae, five in this case from which two are longer.

Pleopods and uropods (Fig. 3 I) as in female.

Remarks. Although the females and males of the species $P$. (M.) angustus n. sp. and Leptochelia lusei are similar, they can be easily distinguished by some details, which entitle me to consider that the new species is bona species. In this respect (as it results from figures 1 A and 2 D-F, and Bamber \& Bird, op. cit.: $123,125$, and figs $12 \mathrm{E}$ and $13 \mathrm{D}, \mathrm{E}, \mathrm{F})$, the females differ by (1) the length of the cheliped carpus (2.7 times as long as wide, in $P$. (M.) angustus $\mathrm{n}$. sp. and only 1.9 in L. lusei), (2) the length of cheliped propodus (2.5 times as long as wide in the new species and only 1.4-1.5 times in L. lusei); (3) the number of the sternal setae on the pereopods V-VI ischium (one in the new species and two in L. lusei), (4) the number 
of the distal setae on the pereopods V and VI propodus (two in the new species and four in L. lusei), (5) the number and length of the distotergal setae of pereopod VII propodus (two long and three short setae in $P$. (M.) angustus $\mathrm{n}$. sp. and one long and four short in $L$. lusei).

The males of P. (M.) angustus n. sp. and L. lusei, differ (besides the cheliped configuration) by (1) the length of the first peduncular article of antennule (about twice as long as second article in the new species and only 1.5 times in L. lusei), (2) the absence of the two setae on pereopod VII carpus in the new species, (3) the presence of four short setae on the pereopod VII propodus in L. lusei, comparatively to three short and two long setae in $P$. (M.) angustus $\mathrm{n}$. sp. (see fig. $3 \mathrm{~B}, \mathrm{H}$ and Bamber \& Bird, op. cit.: figs $14 \mathrm{C}$ and $15 \mathrm{D})$.

\section{Pseudonototanais (Makassaritanais) bamberi n. sp.} (Fig 4)

Material: 1 male, Réunion Island (South-East Indian Ocean), Station 31, lagoon near La Saline-es-Bains, after cyclon "Firinga", mainly from dead corals, 30 January-4 February, 1989; Leg. Dr. Hans-Georg Müller.

Holotype, male, preserved in the collections of "Grigore Antipa" National Museum of Natural History, No. 254509.

Etymology. I dedicated the species to Dr. Roger Bamber in recognition of his numerous contributions to the knowledge on tanaidaceans.

\section{Description of male}

Body (Fig. 4 A) slightly dorsoventarlly flattened, seven times as long as first pereonite width; standard length, $1.6 \mathrm{~mm}$.

Carapace (Fig. 4 A, B) narrower anteriorly, 1.6 times as long as maximum width and slightly longer than the first three pereonites combined, with three short setae on sides. Eyes well defined, pigmented.

Pereon, 3.8 times as long as wide; each pereonite with convex lateral margins. First pereonite shortest, one-fifth as long as carapace, 2.8 times as wide as long, with two setulae on anterolateral corners. Second and third pereonites 1.5 times as long as previous pereonite and 1.7 times as wide as long. Fourth and fifth pereonites longest, twice shorter than carapace, and 1.3 times as wide as long. Sixth pereonite as long as third pereonite. All last five pereonites with one seta on sides.

Pleon as long as fourth and fifth pereonites combined, 1.7 times as long as median width, with five free very short pleonites and a pleotelson (slightly longer than any pleonite). Each pleonite with one conspicuos seta on sides and pleotelson with one median broom and four simple setae on caudal margin (Fig. $4 \mathrm{~J}$ ).

Antennule (Fig. 4 C) slightly shorter than carapace and first pereonite combined, eight-articled. Peduncle three-articled, as long as third and fourth pereonites together; first peduncular article 2.5 times shorter than carapace and 3.5 times as long as wide, with one distal simple and some lateral broom setae; second article 1.5 times shorter than first article and 2.8 times as long as wide, with one long simple and one-two broom setae on distoexternal angle; third peduncular article, two times shorter than first article and narrower than that, with one simple and two-three broom setae, distally. Flagellum five-articled, two times as long as third peduncular article; first four articles with two-three long aesthtascs; fourth article with two simple setae, too; last article very small (tuberculiform), hardly visible, with one aesthetasc and three simple relatively short setae. 


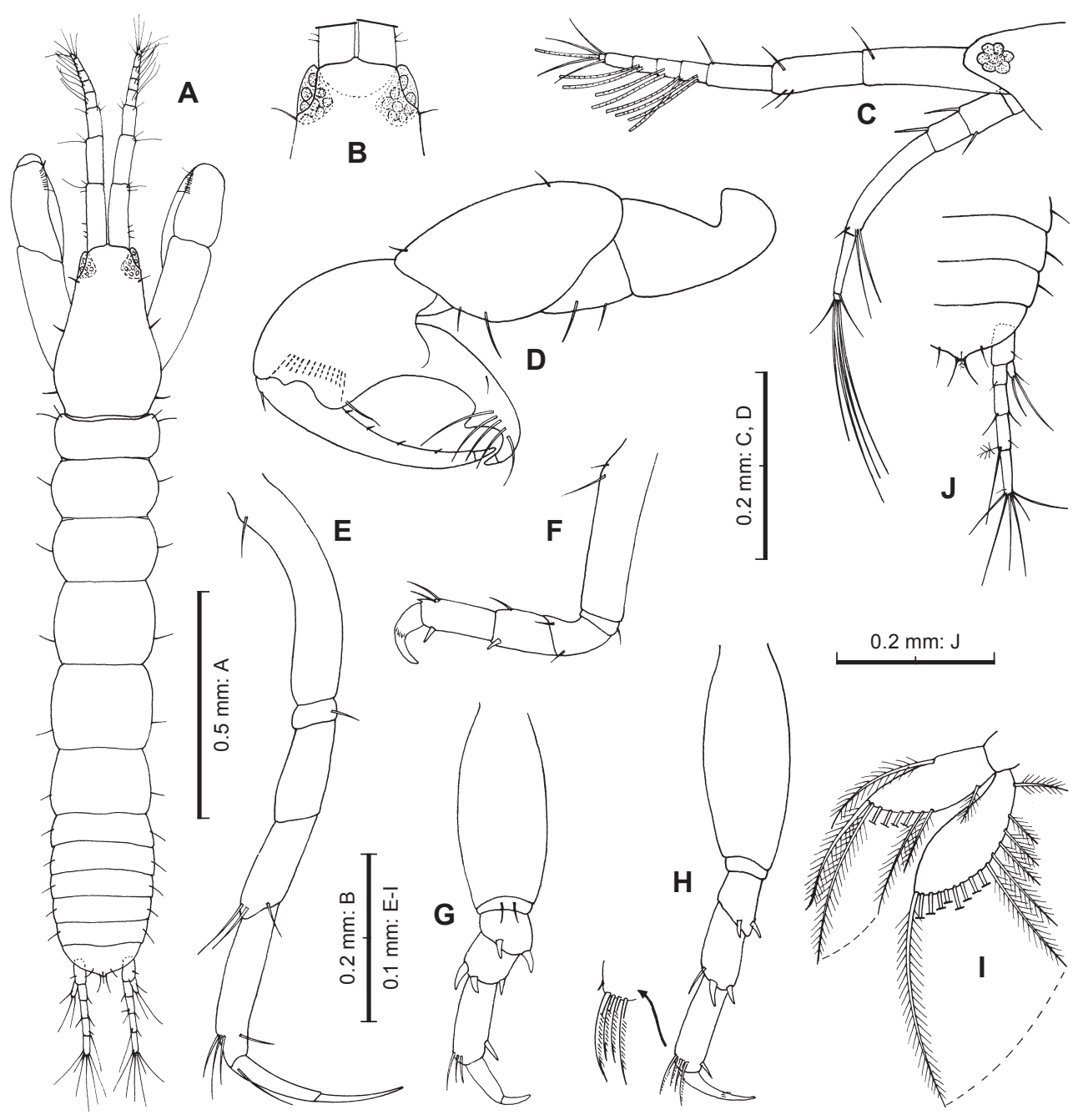

Fig. 4 - Pseudonototanais (Makassaritanais) bamberi n. sp., male, holotype: A, body, dorsal; B, carapace, anterior part; C, antennule and antenna, lateral; D, cheliped, left; E, F, pereopods II and III, respectively; G, H, pereopods V and VII, respectively; I, pleopod III; J, right part of last three pleonite, pleotelson and additional uropod.

Antenna (Fig. 4 C) six-articled, about as long as antennule peduncle; second and third articles combined as long as second peduncular article of antennule; second article with two distal spiniform setae (tergally and sternally); third article with only one distotergal spiniform seta; fourth article 1.4 times as long as previous two articles together but narrower than those, with two very long simple and one small broom seta, distally; fifth article very thin, twice shorter than preceding article, with one distal simple seta; sixth article very small, tuberculiform, with one short and four very long (longer than last three articles combined) simple setae. 
Mouthparts atrophied.

Cheliped (Fig. 4 D) strong, longer than the antennules. Basis two times as long as median width. Merus small, triangular, with two sternal setae. Carpus large, 1.4 times as long as basis and 1.7 times as long as wide, with two tergal and two distosternal setae. Propodus large; palm short but broad with a vertical comb-row of 13 setae; fixed finger thin, strongly curved (sickle-like), with a distoinner denticle and five setae; unguis very small. Dactylus slender, curved, with four or five spinules on the inner margin; unguis slightly longer than that of fixed finger.

Pereopod II (Fig. 4 E) slender, longer than following pereopods. Basis 5.3 times as long as wide, with one short proximotergal simple seta. Ischium very short, with one sternal simple seta. Merus smooth, 2.5 times shorter than basis. Carpus, as long as merus, with three distal simple seta. Propodus, 1.6 times as long as carpus, with four distal simple setae. Dactylus and unguis combined slightly longer than propodus; unguis about as long as dactylus.

Pereopod III (Fig. 4 F) about twice shorter than previous pereopod. Basis 5.3 times as long as wide, with two short proximotergal setae. Ischium with one sternal seta. Merus one-quarter as long as basis, with two distal short setae. Carpus, slightly longer than merus, with one small distosternal spine and one distotergal short seta. Propodus 1.3 times as long as carpus, with two setae and one spine, distotergally and distosternally, respectively. Dactylus thick and short; unguis curved, as long as dactylus.

Pereopod IV similar to pereopod III, but with only one distotergal simple seta on propodus.

Pereopods $V$ (Fig. $4 \mathrm{G}$ ) and VI similar, as long as pereopods III or IV, but stronger than those. Basis swollen, twice as long as median thickness. Ischium with two sternal short setae. Merus thick and very short with two distosternal spines. Carpus, slightly longer than merus, with three distal spines. Propodus about as long as carpus and merus combined, with three distotergal setae and one distosternal spine. Dactylus longer than carpus; unguis about one-half as long as dactylus.

Pereopod VII (Fig. $4 \mathrm{H}$ ) slightly longer than pereopod V. Basis about 2.4 times as long as wide. Merus 0.8 times as long as wide, with two distosternal spines. Carpus 1.4 times as long as merus, with two distosternal spines and one distotergal seta. Propodus 1.3 times as long as carpus, with one distosternal spine and four distotergal ciliate setae. Dactylus and unguis as in pereopod V.

Pleopods (Fig. 4 I) biramous, in five pairs. Peduncle short and thick. Endopod foliaceous, three times as long as wide, with nine plumose setae on outer margin, as figured, and another one median, also plumose, on inner margin. Exopod as long as endopod, with 15 plumose setae on outer margin.

Uropods (Fig. $4 \mathrm{~J}$ ) biramous. Protopod thick, relatively small. Exopod shorter than first endopodal article, with one lateral and two longer terminal simple setae. Endopod four-articled, slender; each of last two articles slightly longer than any of first two articles; setulation as figured.

Remarks. The main features by which the males of P. (M.) bamberi n. sp. distiguish by those of P. (M.) angustus $\mathrm{n}$. sp. consist in the size of antenna (much longer than first two peduncular articles of antennule in first species, figs $3 \mathrm{~B}$ and 4 C). By the males of P. (M.) modestus, comb. nov., P. (M.) bamberi n. sp. distinguishes by the configuration of propodal fixed finger (with a distoinner denticle in the second species, fig. 4 D) and by the number of articles of uropodal endopod (two articles in the first species, cf. Kussakin \& Tzareva, op. cit.: 245 and fig. 4 h, and four in the new species, fig. $4 \mathrm{~J}$ ). 
Females:

Key of the species of the genus Pseudonototanais Lang, 1973

1 - Basis of last three pereopods relatively cylindrical, not much thicker than the basis of previous pereopods; maxilliped basis with two distal simple setae (ssg. Pseudonototanais s. str.)

- Basis of last three pereopods swollen, much thicker than the basis of previous pereopods; maxilliped basis with one to three distal simple setae (ssg. Makassaritanais n. ssg.)

2 - Antenna second article with distotergal spine much longer than that of distosternal one; uropodal endopod five-articled P. (P.) ebriosus

- Antennule second article with distotergal spine about as long as distosternal one; uropodal endopod four-articled at most

3 - Pleopods endopod and exopod with less than 9 and 14 setae, respectively, on outer margin; uropod endopod with three (accidentally four) articles

P. (P.) werthi

- Pleopods endopod and exopod with at least 12 and 17 setae, respectively, on outer margin; uropod endopod with four (accidentally five) articles

P. (P.) bransfieldensis

4 - Maxillipedal basis with one distal seta; uropodal endopod with last article shorter than the first article P. (M.) modestus, comb. nov.

- Maxillipedal basis with 2-3 distal setae; uropodal endopod with last article longer than the first article P. (M.) angustus n. sp.

Males:

1 - Antennule flagellum with two articles, including tuberculiform terminal article (ssg. Pseudonototanais s. str.) $P$. (P.) werthi

- Antennule flagellum with four articles at least, including tuberculiform terminal article (ssg. Makassaritanais n. ssg.)

2 - Inner margin of cheliped fixed finger smooth; uropodal endopod twoarticled P. (M.) modestus, comb. nov.

- Inner margin of cheliped fixed finger with a denticle; uropodal endopod fourarticled

3 - Antenna shorter than first two articles of antennule

- Antenna much longer than first two articles of antennule

P. (M.) angustus n. sp.

P. (M.) bamberi n. sp.

\section{ACKNOWLEDGEMENTS}

I express my gratitude to the late Dr. Hans-Georg Müller for the interesting material offered for study. Special thanks to Prof. Dr. Richard Heard of the Gulf Coast Research Laboratory of the University of Southern Mississippi and to anonymous scientific referees for their useful comments on the manuscript. Also, sincere thanks to my colleague Mihaela Achim-Barcan from "Grigore Antipa" National Museum of Natural History for translating this paper. 


\section{UN SUBGEN ŞI DOUĂ SPECII INDO-VEST-PACIFICE NOI DE LEPTOCHELIIDE DIN GENUL PSEUDONOTOTANAIS LANG, 1973 (CRUSTACEA: TANAIDACEA: TANAIDOMORPHA)}

\section{REZUMAT}

Sunt descrise un subgen, Makassaritanais n. ssg. (aparţinând genului Pseudonototanais Lang, 1973, familia Leptocheliidae) şi două specii, Pseudonototanais (Makassaritanais) angustus n. sp. şi P. (M.) bamberi, din apele marine de mică adâncime de pe coastele insulelor Kalimantan (Strâmtoarea Makassar) şi Réunion (sud-estul Oceanului Indian). În noul subgen a mai fost clasificată şi specia P. (M.) modestus (Kussakin \& Tzareva, 1972), comb. nov., sinonimizată de Lang (1973) cu Pseudonototanais werthi (Vanhoffen, 1914), reconfirmându-se astfel validitatea ei (validitate recunoscută de Shiino, 1978, dar neacceptată de Sieg, 1983). Prin descoperirile făcute numărul speciilor cunoscute din genul Pseudonototanais a crescut de la trei la şase (câte trei pentru fiecare subgen, Pseudonototanais, sensu stricto, şi Makassaritanais n. ssg.). În partea finală a lucrării este prezentată pentru prima dată cheia de identificare a speciilor genului Pseudonototanais, separat pentru femele şi masculi.

\section{LITERATURE CITED}

BAMBER, R. N., G. J. BIRD, 1997 - Peracarid crustaceans from Cape d'Aguilar and Hong Kong, III. Tanaidacea: Tanaidomorpha. Pp. 103-142. In: B. Morton (ed.), The Marine Flora and Fauna of Hong Kong and Southern China Sea IV. Proccedings of the Eighth International Marine Biological Workshop: The Marine Flora and Fauna of Hong Kong and Southern China, Hong Kong, 2-20 April 1995, Hong Kong Univ. Press.

KUSSAKIN, O. G., L. A. TZAREVA, 1972 - Tanaidacea from the coastal zones of the middle Kurile Islands. Crustaceana, Suppliment 3: 237-245.

LANG, K., 1973 - Taxonomische und phylogenetische Untersuchungen über die Tanaidaceen (Crustacea). 8. Die Gattungen Leptochelia Dana, Paratanais Dana, Heterotanais G. O. Sars und Nototanais Richardson, Dazu einige Bemerkungen über die Monokonophora und ein Nachtrag. Zoologica Scripta, 2: 197-229.

SHIINO, 1978 - Tanaidacea collected by French Scientists on Board the Survey Ship "MarionDufresne" in the Regions around Kerguelen Islands and Other Subantarctic Islands in 1972, '74, '75, '76. Science Report of Shima Marineland, 5: 1-122.

SIEG, J., 1973 - Ein Beitrag zum natürlichen System der Dikonophora Lang (Crustacea, Tanaidacea). Inaugural-Dissertation zum Erlangung des Doktorwürde des Math.-Naturwiss. Fak. der Christian-Albrechts-Univ. Kiel, vorgelegt von J. Sieg, 1-298, pls.1-234 (cited after Shiino, 1978).

SIEG, J., 1980 - Revision der Gattung Nototanais Richardson, 1906 (Crustacea, Tanaidacea). Mitteilungen aus dem Zoologischen Museum in Berlin, 56 (1): 45-71.

SIEG, J., 1983 - Tanaidacea, Part 6. Pp. 1-552. In: H. E. Gruner, L. B. Holthuis (eds), Crustaceorum Catalogus, W. Junk Publishers, The Hague.

SIEG, J., 1986 - Tanaidacea (Crustacea) von der Antarktis und Subantarktis. II. Tanaidacea gesammelt von Dr. J. W. Wägele während der Deutschen Antarktis Expedition 1983. Mitteilungen aus der Zoologischen Museum der Universität Kiel, 2 (4): 1-80.

VANHÖFFEN, 1914 - Die Isopoden der Deutschen Südpolar-Expedition 1901-1903. Deutsche Südpolar-Expedition, Zoologie, 15: 447-598.

Received: May 18, 2012

Accepted: July 31, 2012
"Grigore Antipa" National Museum of Natural History Şos. Kiseleff 1, 011341 Bucharest 2, Romania

e-mail: mgutu@antipa.ro 